\title{
Surveillance under dispute: Conceptualising narrative legitimation politics
}

\author{
Christopher Smith Ochoa ${ }^{1 \star}$ (D), Frank Gadinger ${ }^{2}$ and Taylan Yildiz ${ }^{3}$ \\ ${ }^{1}$ NRW School of Governance, Institute of Political Science, University of Duisburg-Essen, Germany, ${ }^{2}$ Käte Hamburger Kolleg \\ / Centre for Global Cooperation Research University of Duisburg-Essen and ${ }^{3}$ NRW School of Governance, Institute of \\ Political Science, University of Duisburg-Essen \\ ${ }^{\star}$ Corresponding author. Email: christopher.smith@uni-due.de
}

(Received 22 November 2019; revised 17 November 2020; accepted 20 November 2020;

first published online 22 December 2020)

\begin{abstract}
Current debates about surveillance demonstrate the complexity of political controversies whose uncertainty and moral ambiguities render normative consensus difficult to achieve. The question of how to study political controversies remains a challenge for IR scholars. Critical security studies scholars have begun to examine political controversies around surveillance by exploring changing security practices in the everyday. Yet, (de)legitimation practices have hitherto not been the focus of analysis. Following recent practice-oriented research, we develop a conceptual framework based on the notion of 'narrative legitimation politics'. We first introduce the concept of 'tests' from Boltanski's pragmatic sociology to categorise the discursive context and different moral reference points (truth, reality, existence). Second, we combine pragmatic sociology with narrative analysis to enable the study of dominant justificatory practices. Third, we develop the framework through a practice-oriented exploration of the Snowden controversy with a focus on the US and Germany. We identify distinct justificatory practices in each test format linked to narrative devices (for example, plots, roles, metaphors) whose fluid, contested dynamics have the potential to effect change. The framework is particularly relevant for IR scholars interested in legitimacy issues, the normativity of practices, and the power of narratives.
\end{abstract}

Keywords: Legitimation; Pragmatic Sociology; Practices; Narrative; Surveillance

\section{Introduction}

Edward Snowden's disclosures cast immediate doubt on the democratic legitimacy of surveillance operations not only within states but across borders. Developed initially as security measures in the aftermath of the September $11^{\text {th }}$ attacks, the epochal privacy violations of the US National Security Agency's (NSA) intelligence activities underscored the inability of parliaments to constrain the extranational nexus of state-corporate mass surveillance. ${ }^{1}$ For critical observers, the rule of law did not apply equally to citizens, government officials, and private corporations alike. ${ }^{2}$ Although public discussions on the erosion of civil liberties in democracies did occur, ${ }^{3}$

\footnotetext{
${ }^{1}$ Nick Couldry and Ulises A. Mejias, The Costs of Connection: How Data is Colonizing Human Life and Appropriating it for Capitalism (Stanford, CA: Stanford University Press, 2019).

${ }^{2}$ See, for example, David Lyon, Surveillance after Snowden (Cambridge, UK: Polity Press, 2015); Shoshana Zuboff, The Age of Surveillance Capitalism (New York: Public Affairs, 2019).

${ }^{3}$ See Pew Research Center, 'Few See Adequate Limits on NSA Surveillance Program: But More Approve than Disapprove' (26 July 2013).

(C) The Author(s), 2020. Published by Cambridge University Press on behalf of the British International Studies Association. This is an Open Access article, distributed under the terms of the Creative Commons Attribution licence (http://creativecommons.org/licenses/by/4.0/), which permits unrestricted re-use, distribution, and reproduction in any medium, provided the original work is properly cited.
} 
widespread surveillance measures continue unabated. Up until today it seems unclear whether surveillance is considered part of the solution to emerging security threats or a major problem in itself. Like other complex and urgent political phenomena of our times (for example, climate change, global migration, the COVID-19 pandemic), the controversy is far from being resolved and thus creates the perception of permanent crisis. Indeed, the characterisation of Snowden 'as America's first traitor-patriot ${ }^{4}$ highlights the necessity for a conceptual framework that grasps the uncertainty and moral ambiguities of disputes in contemporary times.

In a prominent collaboration, Zygmunt Bauman et al..$^{5}$ exemplarily show that surveillance is a complex, inherently interdisciplinary research object located at the junction of the state, the private sector, and public life. For Bauman, ${ }^{6}$ this complexity results from a liquid modernity in which rapid globalisation has fundamentally challenged local and national institutions' ability to, among other things, provide security. This has generated societies characterised by extraordinary 'uncertainty at the level of individuals and a problematization of trust in, and legitimacy of, institutions and experts in an interconnected world'. ${ }^{7}$ Most research perspectives around critical security, surveillance, and cultural studies examine the ambivalence of modernity and its transformative normative effect on our everyday lives as liberal subjects in a digital age. ${ }^{8}$ Although such critical research perspectives have investigated surveillance by focusing on its everyday normalisation through practices and materiality and provide valuable insight into the ontology of surveillance and its mediatising role in human life, ${ }^{9}$ few studies have engaged with the political (de)legitimation practices around the surveillance nexus itself. ${ }^{10}$ This points to a gap in surveillance and security studies in addressing legitimacy and uncertainty in politics and a need for more conceptual and empirical efforts to unveil the dynamics of these political controversies. ${ }^{11}$

The surveillance nexus is no exception to Andrew Barry's observation that those involved in political controversies often 'not only disagree about what is known about a problem, and why it matters, but also about the existence of the very problem about which they disagree'. ${ }^{2}$ Therefore, a legitimacy-oriented view on ongoing normative contestation should not isolate controversies as single events, but study them in their larger relational context within a moving field of contentions, ${ }^{13}$ conflicts, and events. In this vein, practice-oriented scholars, mainly using assemblage and actor-network-theory, emphasise the contested ways by which surveillance knowledge is

\footnotetext{
${ }^{4}$ Allison Stanger, Whistleblowers: Honesty in America from Washington to Trump (New Haven, CT: Yale University Press, 2019), p. 169.

${ }^{5}$ Zygmunt Bauman et al., 'After Snowden: Rethinking the impact of surveillance', International Political Sociology, 8:2 (2014), pp. 121-44.

${ }^{6}$ Zygmunt Bauman, Liquid Times: Living in an Age of Uncertainty (Cambridge, UK: Polity Press, 2007), pp. 7-9.

${ }^{7}$ William G. Staples, Everyday Surveillance: Vigilance and Visibility in Postmodern Life (Lanham, MD: Rowman and Littlefield, 2013), p. 9.

${ }^{8}$ See, for example, Torin Monahan, 'Surveillance as cultural practice', The Sociological Quarterly, 52:4 (2011), pp. 495-508; David Chandler and Julian Reid, The Neoliberal Subject: Resilience, Adaptation, and Vulnerability (Lanham, MD: Rowman and Littlefield, 2016).

${ }^{9}$ See, for example, David Lyon, The Culture of Surveillance: Watching as a Way of Life (Cambridge, UK: Polity Press, 2018); Edward Snowden, Permanent Record (New York: Metropolitan Books, 2019).

${ }^{10}$ Rita Olesker, 'The securitisation dilemma: Legitimacy in securitisation studies', Critical Studies on Security, 6:3 (2018), pp. 312-29 (p. 312); similarly Didier Bigo, 'Security, surveillance, and democracy', in Kirstie Ball, Kevin D. Haggerty, and David Lyon (eds), Routledge Handbook of Surveillance Studies (New York: Routledge Press, 2012), pp. $277-84$.

${ }^{11}$ See, however, Matthias Schulze, 'Patterns of surveillance legitimization: The German discourse on the NSA scandal', Surveillance \& Society, 13:2 (2015), pp. 197-217; Valentin Gros, Marieke de Goede, and Beste İşleyen, 'The Snowden Files made public: A material politics of contesting surveillance', International Political Sociology, 11:1 (2017), pp. 73-89; Rita Floyd, The Morality of Security: A Theory of Just Securitization (Cambridge, UK: Cambridge University Press, 2019).

${ }^{12}$ Andrew Barry, 'Political situations: Knowledge controversies in transnational governance', Critical Policy Studies, 6:3 (2012), pp. 324-36 (p. 330).

${ }^{13}$ 'Contentious politics' could be considered another current in political sociology to study political controversies. See, for example, Emilio Lehoucq and Sidney Tarrow, 'The rise of a transnational movement to protect privacy', Mobilization: An International Quarterly, 25:2 (2020), pp. 161-84.
} 
produced and circulated in relational networks between humans, objects, and devices. ${ }^{14}$ Our contribution follows practice-oriented scholarship that analyses 'the concrete and materially embedded struggles and strategies of knowing, contesting, claiming, and solving the implications ${ }^{15}$ of the surveillance nexus from an interpretive, micro-oriented view. To do this, we build a conceptual framework to study narrative legitimation politics by highlighting the contestation, justification, and production of legitimacy in political controversies. ${ }^{16}$ We develop this through an exploration revealing dominant justificatory practices after the Snowden disclosures. Moreover, we show how these practices are necessarily embedded in narrative modes of political communication that appeal to the governed to achieve legitimacy in public discourse.

We first argue that Luc Boltanski's pragmatic sociology ${ }^{17}$ provides a useful methodological background and conceptual framework necessary to study political controversies. ${ }^{18}$ His pragmatist notion of 'test' is a useful conceptual tool to explore the vast spectrum of disputes, in which political actors shape reality by legitimising and/or criticising policies. ${ }^{19}$ Importantly, tests delineate how actors, according to their (non-)institutional position, handle uncertainty resulting from a controversy. We differentiate between three kinds of tests characterised by distinct points of moral reference: truth, reality, and existence. We therefore assume that these three test formats encompass the multidimensionality of legitimation disputes occurring at different sites of the political sphere. We further argue that justificatory practices ${ }^{20}$ are articulated in modes of political storytelling to reach a wider audience in respective cultural contexts. Following recent IR research, ${ }^{21}$ we see great promise in the interdisciplinary research field of narrative analysis ${ }^{22}$ to

\footnotetext{
${ }^{14}$ See, for example, Peer Schouten, 'Security as controversy: Reassembling security at Amsterdam airport', Security Dialogue, 45:1 (2014), pp. 23-42; Marieke de Goede, 'The chain of security', Review of International Studies, 44:1 (2018), pp. 24-42; Rocco Bellanova, 'Digital, politics, and algorithms: Governing digital data through the lens of data protection', European Journal of Social Theory, 20:3 (2017), pp. 329-47; Jef Huysmans, 'Democratic curiosity in times of surveillance', European Journal of International Security, 1:1 (2016), pp. 73-93.

${ }^{15}$ Gros, de Goede, and İşleyen, 'The Snowden Files made public', p. 76.

${ }^{16}$ See for earlier, similar attempts, Christian Reus-Smit, 'International crises of legitimacy', International Politics, 44:2-3 (2007), pp. 157-74; Jens Steffek, 'The legitimation of international governance: A discourse approach', European Journal of International Relations, 9:2 (2003), pp. 249-75; Stacie E. Goddard, 'Uncommon ground: Indivisible territory and the politics of legitimacy', International Organization, 60:1 (2007), pp. 35-68; see, for recent suggestions, Daniel F. Wajner, “'Battling” for legitimacy: Analyzing performative contests in the Gaza flotilla paradigmatic case', International Studies Quarterly, Online First (2019); Joseph MacKay, 'Legitimation strategies in international hierarchies', International Studies Quarterly, 63:3 (2019), pp. 717-25.

${ }^{17}$ Luc Boltanski and Laurent Thévenot, On Justification: Economies of Worth (Princeton: Princeton University Press, 2006). Boltanski has worked with figures such as Laurent Thévenot and Ėve Chiapello to develop pragmatic sociology. However, Boltanski has become the spearhead of this intellectual project.

${ }^{18}$ See Frank Gadinger, 'On justification and critique: Luc Boltanski's pragmatic sociology and International Relations', International Political Sociology, 10:3 (2016), pp. 187-205; Tine Hanrieder, 'Orders of worth and the moral conceptions of health in global politics', International Theory, 8:3 (2016), pp. 390-421; Max Lesch, 'Multiplicity, hybridity and normativity: Disputes about the UN convention against corruption in Germany', International Relations, Online First (2020); Holger Niemann, The Justification of Responsibility in the UN Security Council: Practices of Normative Ordering in International Relations (London: Routledge, 2019); Médéric Martin-Mazé, 'Returning struggles to the practice turn: How were Bourdieu and Boltanski lost in (some) translations and what to do about it?', International Political Sociology, 11:2 (2017), pp. 203-20.

${ }^{19}$ See recently, Dominique Linhardt and Moreau de Bellaing, 'The "enemization" of criminal law? An inquiry into the sociology of a legal doctrine and its political and moral underpinnings', International Political Sociology, 13:4 (2019), pp. 447-63.

${ }^{20}$ The concept of justificatory practices always implies both critique and justification in its mutual relationship; see Boltanski and Thévenot, On Justification, p. 25.

${ }^{21}$ See, for example, Katja Freistein and Frank Gadinger, 'Populist stories of honest men and proud mothers: A visual narrative analysis', Review of International Studies, 46:2 (2020), pp. 217-36; Kai Oppermann and Alexander Spencer, 'Narrating success and failure: Congressional debates on the "Iran nuclear deal"', European Journal of International Relations, $24: 2$ (2018), pp. 268-92.

${ }^{22}$ See, for example, Albrecht Koschorke, Fact and Fiction: Elements of a General Theory of Narrative (Berlin and Boston: De Gruyter, 2018); Mieke Bal, Narratology: Introduction to the Theory of Narrative (Toronto: University of Toronto Press, 2009);
} 
capture how competing understandings of surveillance lead to the perception of ongoing contestation and permanent crisis.

Our article therefore contributes first to current debates on the rise of global surveillance by building on recent practice-oriented research and complementing it with a new perspective on public legitimation disputes, foregrounding the justification and critique of the surveillance nexus. Second, the adoption of pragmatic sociology's notion of 'test' enriches recent conceptual debates on including pragmatist approaches to IR's practice $\operatorname{turn}^{23}$ and provides another useful tool for IR scholars to study controversies as done by assemblage and actor-network theorists. ${ }^{24}$ Finally, the combination of pragmatic sociology with narrative analysis demonstrates the analytical promise of 'doing praxiography' in the rather undogmatic tradition of practice-oriented research methodology using different research techniques (including visual analysis as, for instance, in our analysis). ${ }^{25}$ That is, the constant oscillation between theoretical and empirical work enables (and forces) researchers to develop 'sensitizing frameworks ${ }^{26}$ depending on their research aim and chosen cases. ${ }^{27}$

In the following, we present our conceptual framework by reconstructing the evolution of debates on relational notions of legitimacy in IR, highlighting the distinctive added value of a pragmatic sociological perspective on legitimation. Second, we outline the promising compatibility of pragmatic sociology and narrative analysis. Third, we identify and analyse dominant justificatory practices after the Snowden disclosures in Germany and the US in their respective test formats. Lastly, we conclude our findings.

\section{Pragmatic legitimacy through 'tests' and narrative}

Rising interest in micro-oriented approaches in $\mathrm{IR}^{28}$ has sparked debates on the analysis of legitimacy. Consequently, constructivist and practice-oriented scholars now both argue that legitimacy should no longer be understood as a state-centred essentialist category anchored in formal governance routines such as elections. Instead, largely through the influence of democratic ${ }^{29}$ and political ${ }^{30}$ theorists, legitimacy should be understood as a more fragile, politicised phenomenon in nearly all institutional spheres of world politics. ${ }^{31}$ The terminological shift in many studies from 'legitimacy' to 'legitimation' and (de)legitimising processes underlines the

Barbara Czarniawska, Narratives in Social Science Research (London: Sage, 2004); Margaret R. Somers, 'The narrative construction of identity: A relational and network approach', Theory \& Society, 23:5 (1994), pp. 605-49.

${ }^{23}$ See, for example, Andreas Grimmel and Gunther Hellmann, 'Theory must not go on holiday: Wittgenstein, the pragmatists, and the idea of social science', International Political Sociology, 13:2 (2019), pp. 198-214; Sebastian Schindler and Tobias Wille, 'How can we criticize international practices?', International Studies Quarterly, 63:4 (2019), pp. 1014-24; Sasikumar S. Sundaram and Vineet Thakur, 'A pragmatic methodology for studying international practices', Journal of International Political Theory, Online First (2019).

${ }^{24}$ See, for example, Barry, 'Political situations'; Christian Bueger, 'Territory, authority, expertise: Global governance and the counter-piracy assemblage’, European Journal of International Relations, 24:3 (2018), pp. 614-37.

${ }^{25}$ See Christian Bueger and Frank Gadinger, International Practice Theory (Cham: Palgrave MacMillan, 2018), ch. 6 (pp. 131-62).

${ }^{26}$ Ibid., p. 135.

${ }^{27}$ See, for similar attempts to combine the analysis of practices and narratives, Dylan M. H. Loh, “"The Chinese dream” and the "Belt and Road Initiative": Narratives, practices, and sub-state actors', International Relations of the Asia-Pacific (2019); Alisher Faizullaev and Jerémie Cornut, 'Narrative practice in international politics and diplomacy: The case of the Crimean crisis', Journal of International Relations and Development, 20:3 (2017), pp. 578-604.

${ }^{28}$ Ty Solomon and Brent J. Steele, 'Micro-moves in International Relations theory', European Journal of International Relations, 23:2 (2017), pp. 267-91.

${ }^{29}$ See, for example, Pierre Rosanvallon, Democratic Legitimacy: Impartiality, Reflexivity, Proximity (Princeton, NJ: Princeton University Press, 2011).

${ }^{30}$ See, for example, Raymond Geuss, Philosophy and Real Politics (Princeton: Princeton University Press, 2008).

${ }^{31}$ See, for example, Achim Hurrelmann et al. (eds), Legitimacy in an Age of Global Politics (Basingstoke: Palgrave MacMillan, 2008). 
micro-oriented emphasis on claims, practices, and strategies. ${ }^{32}$ Furthermore, this shift corresponds to growing interest in the 'politics of legitimacy' or 'politics of legitimation'. ${ }^{33}$ In line with sociological conflict theories, normative disputes are not regarded as a systemic error, as state-centred concepts suggest, but as a productive source for democratic politics.

Christian Reus-Smit summarises this practice-oriented notion on legitimacy issues by stressing the dynamic nature of producing legitimacy in terms of social perception and recognition in 'practices of legitimation'. ${ }^{34}$ He suggests unpacking how actors make legitimacy claims, which he considers 'the lifeblood of the politics of legitimation'. ${ }^{35}$ Although Reus-Smit remains vague on how to study this 'lifeblood', his plea has stimulated renewed interest in politicisation, public voices, and resistance against formal authorities while encouraging scholarship to find ways to capture the 'legitimation work' of ordinary actors. ${ }^{36}$

As Joseph MacKay argues, more work in IR is needed on uncovering the hierarchical multidimensionality of legitimacy since it is not simply created by heads of state, but also civil society, parliamentarians, and average citizens. ${ }^{37}$ While some IR scholars rightly conclude that legitimacy studies should transcend the normative claims of elites and dedicate more attention to ordinary actors' assertions, we focus on how elites and ordinary actors tap into registers of everyday life to justify or criticise the surveillance nexus. ${ }^{38}$ To this end, we repurpose Boltanski's sociological work, in particular his concept of 'test', for IR to more precisely understand how justification and critique draw on the everyday. We furthermore consider it fruitful to combine this concept with narrative approaches, which contend that justificatory practices gain practical force by tapping into the everyday via stories that might be 'accepted, rejected, or improved upon by the partners in the conversation'.39

\section{From legitimation to justification}

Boltanski aims to place 'justification' at the heart of analysis. This could be misleadingly understood as a research aim to develop a normative theory of justice. In contrast to such attempts, he understands justification as a social practice through which diverging claims are tested under conditions of uncertainty. ${ }^{40}$ The processual term of legitimation shifts the focus to the imperative of justification in disputes of everyday life. ${ }^{41}$ While state-centred concepts define legitimation (that is, reasoning) as the process though which actors articulate claims in line with the pre-established rules of rational ethics (from the standpoint of normative theories) or regime regulations (from the standpoint of institutional theories), pragmatic sociology is interested in legitimation as a non-linear interplay between critique and justification in the everyday; that is, examining how actors mobilise an ordinary 'sense of justice', use 'critical capacities', and resist the inertia created by dominant institutional structures. ${ }^{42}$ This epistemic premise implies a different form of 'pragmatic critique', which is motivated 'by a distinct vision of social progress that consists in empowering people to act together'. ${ }^{43}$

\footnotetext{
${ }^{32}$ See Niemann, The Justification of Responsibility in the UN Security Council; Wajner, “Battling” for legitimacy'; Ian Hurd, After Anarchy: Legitimacy and Power in the UN Security Council (Princeton: Princeton University Press, 2007).

${ }^{33}$ See Reus-Smit, 'International crises of legitimacy'; Goddard, 'Uncommon ground'.

${ }^{34}$ Reus-Smit, 'International crises of legitimacy', p. 159.

${ }^{35}$ Ibid.

${ }^{36}$ Geuss, Philosophy and Real Politics, p. 35; see also Michael Zürn et al., 'International authority and its politicization', International Theory, 4:1 (2012), pp. 69-106.

${ }^{37}$ MacKay, 'Legitimation strategies in international hierarchies'.

${ }^{38}$ See, for example, Steffek, 'The legitimation of international governance'.

${ }^{39}$ Czarniawska, Narratives in Social Science Research, p. 5; see also Koschorke, Fact and Fiction.

${ }^{40}$ Gadinger, 'On justification and critique', p. 193.

${ }^{41}$ Luc Boltanski, Love and Justice as Competences (Cambridge: Polity Press, 2012), p. 28.

${ }^{42}$ Luc Boltanski and Laurent Thévenot, 'The sociology of critical capacity', European Journal of Social Theory, 2:3 (1999), pp. 361-3; Luc Boltanski, On Critique: A Sociology of Emancipation (Cambridge: Polity Press, 2011), p. 30.

${ }^{43}$ Schindler and Wille, 'How can we criticize international practices?', p. 1016.
} 
How, then, do these critical moments materialise? For Boltanski, they resemble 'the scene of a trial, in the course of which actors in a situation of uncertainty proceed to investigations, record their interpretations of what happens in reports, establish qualifications and submit to tests. ${ }^{44}$ The pragmatist notion of 'test' sheds light on how actors resolve uncertainty expressed in critical everyday moments. Tests in a general sense 'refer to the way reality is shaped'. ${ }^{45}$ Focusing on reality means embracing both cognitive and practical ends that reveal indices for collective struggles in pursuit of a moral sense of community. The importance of tests lies in their ability to designate procedures 'capable of reducing the uncertainty of a situation through the achievement of agreement as to the qualification of the beings involved ... a test encompasses both an evaluation according to a moral standard and an assessment according to the standard of truth'. ${ }^{46}$

The major advantage of pragmatist research methodology's focus on controversies (in contrast to routines) lies in political actors' need to make competing moral claims visible since these situations question 'what is good, just, right, or appropriate in the course of practice, and creates an occasion for deliberation in politics' ${ }^{47}$ The term 'controversy', in which different 'disputes' occur, is therefore not random as it follows a rather agency-oriented understanding. This contrasts with the hierarchical character of 'struggles' in Bourdieusian theory, whose results are seldom surprising due to the reproduced character of stratification practices. ${ }^{48}$ Furthermore, a key feature of controversies is the primacy of contention and multiplicity, as disagreeing actors are often uncertain over the worths of people in situations. ${ }^{49}$ Pragmatic sociology assumes that actors prove their moral claims by mobilising orders of worth and distinct criteria of equivalence to evaluate their relative worth against each other in a process of 'normative ordering'. ${ }^{50}$ Orders of worth are understood as 'repertoires of evaluation consisting of moral narratives and objects that enable tests of worth'. 51

\section{Legitimation disputes as different kinds of test}

In On Critique, Boltanski refines the notion of 'test' by relating it to the discussion on institutions' power and complex domination. For him, the main pragmatist contribution to sociology has been 'to underline the uncertainty that threatens social arrangements and hence the fragility of reality', adding it stops half way when it places too much confidence in the ability of actors to reduce this uncertainty'. ${ }^{52}$ This means considering the constant unease about what is (not) valid, latent in situations in which order is seemingly established and forcefully defended in moments of dispute. ${ }^{53}$ Whereas Bourdieu places uncertainty into a black box located in actors' individuality, Boltanski stresses the creative and unpredictable productivity of critique as a driving motor for social transformation. ${ }^{54}$

As Table 1 shows, he proposes an analytically useful distinction between three kinds of tests to interpretively reconstruct justificatory practices in speech acts; that is, truth, reality, and existential tests. $^{55}$ In line with recent IR research, truth tests are based on justification through

\footnotetext{
${ }^{44}$ Boltanski, On Critique, p. 25, emphasis in original.

${ }^{45}$ Tanja Bogusz, 'Why (not) pragmatism?', in Simon Susen and Bryan Turner (eds), The Spirit of Luc Boltanski: Essays on the Pragmatic Sociology of Critique (London: Anthem Press, 2014), pp. 129-52 (p. 135).

${ }^{46}$ Boltanski and Thévenot, On Justification, p. 30.

${ }^{47}$ Sundaram and Thakur, 'A pragmatic methodology for studying international practices', p. 7, emphasis in original.

${ }^{48}$ See Martin-Mazé, 'Returning struggles to the practice turn', for this useful distinction.

${ }^{49}$ See Lesch, 'Multiplicity, hybridity and normativity'.

${ }^{50}$ Niemann, The Justification of Responsibility in the UN Security Council, p. 84; Boltanski and Thévenot, On Justification, p. 133.

${ }^{51}$ Hanrieder, 'Orders of worth', p. 391.

${ }^{52}$ Boltanski, On Critique, p. 54.

${ }^{53}$ Ibid., p. 57.

${ }^{54}$ Bogusz, 'Why (not) pragmatism?', p. 136.

${ }^{55}$ Boltanski, On Critique, pp. 103-10.
} 
Table 1. Boltanski's three test formats.

\begin{tabular}{|c|c|c|c|}
\hline $\begin{array}{l}\text { Test } \\
\text { format }\end{array}$ & $\begin{array}{l}\text { Legitimation } \\
\text { form }\end{array}$ & Key features & Typical speech acts \\
\hline Truth & Confirmation & $\begin{array}{l}\text { 'Maniacal quest for coherence'. } \\
\text { Repetitive, routinised remarks } \\
\text { re-establishing authority and } \\
\text { promising security with a return to } \\
\text { 'normalcy' } \\
\rightarrow \text { Order is restored }\end{array}$ & $\begin{array}{l}\text { Style typically conveyed by heads } \\
\text { of state, advisors, leaders, } \\
\text { cabinet members, press } \\
\text { secretaries } \\
\text { Stylised speech }\end{array}$ \\
\hline Reality & Critique & $\begin{array}{l}\text { Disagreement on what reality actually is. } \\
\text { Use of acceptable measuring } \\
\text { instruments, proofs, objects (e.g., } \\
\text { statistics). Reformatory with strong } \\
\text { belief in values of established } \\
\text { institutions } \\
\rightarrow \text { Order is improved }\end{array}$ & $\begin{array}{l}\text { Style typically expressed by } \\
\text { members of parliament, } \\
\text { mainstream journalists, } \\
\text { investigators } \\
\text { Scrutinising speech }\end{array}$ \\
\hline Existential & Refusal & $\begin{array}{l}\text { Radical. Questioning the legitimacy of } \\
\text { existence of established institutions. } \\
\text { Occurs outside of their confines } \\
\text { (protests, film, street art, novels, } \\
\text { poetry) } \\
\rightarrow \text { Order is failing }\end{array}$ & $\begin{array}{l}\text { Style typically articulated by } \\
\text { artists, activists, civil society, } \\
\text { intellectuals, ordinary citizens } \\
\text { Accusatorial speech }\end{array}$ \\
\hline
\end{tabular}

confirmation. ${ }^{56}$ A key feature of this kind of test is actors' 'quest for coherence' through established cues or rituals in language. ${ }^{57}$ Typical ways to mobilise this justificatory action is through ceremonies and modes of representation such as statements, performances, and gestures. In truth tests, actors often use metaphors to generate a common feeling of confidence in existing institutions (for example, the widely used claim of the European Union as an 'anchor of stability'). Politicians giving unscripted but routine speeches that become awkward, or ceremonies ending due to unexpected circumstances exemplify how these tests can fail. ${ }^{58}$ Unfortunate wording or actions such as Chancellor Angela Merkel's expression of joy after the news of Osama bin Laden's death can result in unease in an otherwise routine situation. Official statements by heads of state and their representatives in government in the immediate aftermath and the following fallout of a crisis are apt for analysis.

In contrast to truth tests, the two other test formats provide opportunities to criticise powerful structures of institutions and unmask hermeneutical contradictions. Reality tests are employed to reflect and critique in moments of disagreement. Whereas truth tests seek to reinforce the existing order while reducing uncertainty, reality tests can either validate existing realities or disrupt them by unmasking contradictions and revealing forgotten dimensions of reality. ${ }^{59}$ Critique can be employed in reality tests by denouncing perceived conditions of injustice, demanding more evidence for illegitimate claims, or questioning procedures and formats. Public demands for state officials' resignation are exemplary as arguments claim the reputation of an institution will be damaged in the long term. Challenges often transpire on the floor of parliament or committees of inquiry, making institutional mechanisms through which the effectiveness of political institutions is a tested prime example of this format. Every time a politician or activist evokes social justice or respect for established rules and procedures in institutional contexts, reality tests are at work. Print media opinion pieces and parliamentary committee records are particularly useful for analysis.

\footnotetext{
${ }^{56}$ See Linhardt and Moreau de Bellaing, 'The "enemization" of criminal law?'.

${ }^{57}$ Boltanski, On Critique, p. 103.

${ }^{58}$ Ibid., p. 105.

${ }^{59}$ Ibid., p. 106.
} 
The third format, existential tests, is the most radical. Whereas reality tests embody reformist critique, existential tests fundamentally probe the status quo through critiques transcending procedural routines. They question the existential legitimacy of the current power structure and emphasise marginalised voices. To invoke existential tests, actors base their arguments on experiences, such as suffering, injustice, humiliation, and shame. ${ }^{60}$ They appeal to collectivity in a situation perceived as fundamentally unacceptable and should outrage more people. Due to the lack of established test formats, existential legitimacy claims are difficult to formulate. Therefore, actors reject established, institutionalised forms of expression and turn to alternative outlets: for example, art, social media, protests, and other creative channels such as The Onion's satirical takes on American politics as a powerful form of critique. ${ }^{61}$ Radical critique is challenged by repudiatory accusations of 'subjectivity', 'paranoia', and 'hysteria' as they mobilise a variety of emotional registers. $^{62}$ The consideration of art, tweets, and film as relevant sources of politics is a relatively new trend corresponding to the narrative, aesthetic, and visual turn in IR. ${ }^{63}$

\section{Doing pragmatic sociology with narrative analysis}

A narrative approach presents a useful, perhaps necessary, methodological bridge to Boltanski's pragmatic sociology, which, first, illustrates how political controversies are articulated in test formats. Hence, controversies do not just simply result in justifications. They must be narrated in a way that resonates with target audiences' everyday experiences. Michel de Certeau holds storytelling to be the most relevant mode of everyday communication, acting as a 'glue' stabilising time and space. ${ }^{64}$ How this is told determines the formats in which the controversies emerge (see Table 1). Following recent narrative scholarship, ${ }^{65}$ we suggest that metaphors, roles, and plots are key devices and promising analytical objects for reconstructing constellations of practices and narratives. Metaphors provide access into different modes of knowing in highly complex situations whose objectivity is bound to agreement in communicative acts and competing normative expectations. ${ }^{66}$ Puzzling phenomena such as the Snowden disclosures and the emergence of new encryption technologies, ${ }^{67}$ for instance, result in the use of metaphors that shape political reality and policy measures. Accordingly, metaphors can be understood as 'mini-narratives' that yield insight into what a cultural community considers acceptable. ${ }^{68}$

Second, narratives are important in reconstructing how narrators gain legitimacy and how agency is ascribed. Examples include categorising actors as good and evil or heroes and villains. This has been referred to as 'character funnelling', which simultaneously reduces complexity and intensifies 'evaluation in a way that encourages political alliances and galvanizes political action' ${ }^{69}$ However, this process leads to asymmetric moral judgements that 'fulfill a double-task, on the one hand polarizing and on the other hand generating unity, hence integration, through the polarization' ${ }^{70}$

${ }^{60}$ Ibid., pp. $107-08$.

${ }^{61}$ Ibid.

${ }^{62}$ Ibid., p. 108.

${ }^{63}$ See, for example, Roland Bleiker (ed.), Visual Global Politics (London and New York: Routledge, 2018).

${ }^{64}$ Michel de Certeau, The Practice of Everyday Life (Berkeley: University of California Press, 1988), p. 70.

${ }^{65} \mathrm{See}$, for example, Oppermann and Spencer, 'Narrating success and failure'; Freistein and Gadinger, 'Populist stories of honest men and proud mothers'; Frank Gadinger, Christopher Smith Ochoa, and Taylan Yildiz, 'Resistance or thuggery? Political narratives of urban riots', Narrative Culture, 6:1 (2019), pp. 88-111.

${ }^{66}$ Dvora Yanow, How Does a Policy Mean? (Washington, DC: Georgetown University Press, 1996), p. 132.

${ }^{67}$ See, for example, Lex Gill, 'Law, metaphor, and the encrypted machine', Osgoode Hall Law Journal, 55:2 (2018), pp. 44077.

${ }^{68}$ Bal, Narratology, p. 35.

${ }^{69}$ Ronald N. Jacobs and Sarah Sobieraj, 'Narrative and legitimacy: U.S. congressional debates about the nonprofit sector', Sociological Theory, 25:1 (2007), pp. 1-25 (p. 8).

${ }^{70}$ Koschorke, Fact and Fiction, p. 75. 
Third, Boltanski's pragmatic sociology benefits from narratology's central concept of emplotment, which serves to better understand how actors chronologically imagine situations and consequently select specific justificatory practices. Emplotment refers to the act of contextualising an event into a plot pattern by assigning it a beginning, middle, and an end. This provides meaning to independent instances by translating them 'into episodes ${ }^{71}$ that would otherwise be isolated. Furthermore, emplotment is a highly selective process that defines which events matter and which characters are recognised in ongoing debates. As Deborah Stone has shown, policy controversies are often told in the tradition of classic plot patterns described by Hayden White as comedy, romance, tragedy, and satire. ${ }^{72}$ As we will see, competing narratives around the Snowden controversy also operate with similar plot patterns to make sense of the puzzling event and to provide guidance for the future.

\section{Some remarks on research techniques: 'Zooming in and out' of controversies}

We follow the methodological notion of praxiography as used in practice-oriented research strategies. Thus, we aim to 'record, to describe and to reconstruct' to understand 'practices and their configurations. ${ }^{73}$ To study controversies, Boltanski's pragmatic sociology and narrative analysis can be regarded as promising sensitising frameworks. ${ }^{74}$ Generally, we rely on a strategy that Davide Nicolini and others describe in practice-oriented research as 'zooming in, zooming out'. $^{75}$ The objective is to reconcile practice theoretical assumptions with a research strategy that enables observing how practices and narratives are interlinked. Thus, the first step is to study a configuration by zooming in on a distinct element (for example, a metaphor, an object, a storytelling device); the second step is then to zoom out to gather an understanding of the effects of the element and to unfold the wider discursive context. ${ }^{76}$

Although collected material already features its own framing devices and agendas, the advantage of narrative analysis is that it takes into account actors' perspectives as practices of storytelling. This constitutes the messy, complex 'social reality' in which storytelling takes place. ${ }^{77}$ To develop the sensitising framework through interpretive analysis, we collected text and visuals interconnected in their focus on the Snowden revelations. Going through the material, we created a corpus of online news articles (65), ${ }^{78}$ parliamentary and executive protocols (15), non-fiction books (6), a YouTube video, and films (4) that covered a variety of positions and information. To identify justificatory practices while engaging with the empirical corpus material through an exploration of 'justification work' in legitimacy claims, we interpreted the material in terms of its sense-making implications. ${ }^{79}$ That is, the aim of the analytical process is to capture how the objects of the study interpret their world around them. ${ }^{80}$ In this context, situated judgements expressed in the form of 'everyday talk' through dispute were an important ground for the analysis. ${ }^{81}$ We therefore particularly focused on moments in text and film where 'the confrontation

\footnotetext{
${ }^{71}$ Somers, 'The narrative construction of identity', p. 616.

${ }^{72}$ See Hayden White, The Content of the Form: Narrative Discourse and Historical Representation (Baltimore, MD: The Johns Hopkins University Press, 1987).

${ }^{73}$ Bueger and Gadinger, International Practice Theory, p. 132.

${ }^{74}$ Ibid., p. 140.

${ }^{75}$ Davide Nicolini, Practice Theory, Work \& Organization (Cambridge: Cambridge University Press, 2013).

${ }^{76}$ Bueger and Gadinger, International Practice Theory, p. 141.

${ }^{77}$ See, for example, Kim Etherington, Becoming a Reflexive Researcher (London: Jessica Kingsley, 2004), p. 81.

${ }^{78}$ The newspaper articles were selected by using various search terms that recurred in the material and were thus connected to our research interest. Examples of search terms in English and German: 'Snowden Congress', 'Snowden Obama', 'Snowden Merkel', 'Snowden Art', 'Snowden film', 'Snowden protest', 'Snowden traitor', and 'Snowden hero'. The major focus on the United States and Germany is reasoned by their centrality in the aftermath of the revelations. All translations are ours.

${ }^{79}$ Gadinger, 'On justification and critique', p. 199.

${ }^{80}$ Boltanski and Thévenot, On Justification, p. 4.

${ }^{81}$ de Goede, 'The chain of security', p. 39.
} 
between different forms of judgement expressed by the different actors', thereby making interpretive practices evident. ${ }^{82}$ This methodology resonates with other interpretive work in IR, for instance the literature on symbolic and discursive legitimacy. ${ }^{83}$

We manually coded the text material to identify key terms and tropes. Drawing on the 'distanced' pragmatist Wittgensteinian tradition, ${ }^{84}$ we identified narrative patterns and justificatory practices. Tapping into everyday registers proved particularly useful in reconstructing relevant narrative patterns (zooming in). ${ }^{85}$ In another step, we studied films, applying the identified patterns and practices to test their significance, making note of particular scenes that resonated specifically with the framework of analysis. In a further analytical step, we used 'axial coding, ${ }^{86}$ that is, material-based coding, to develop categories (presented in Table 1) by accounting for changes across time and relating speech acts to one another by organising, linking, and comparing. Furthermore, we reinterpreted these findings to generalise and identify the concrete yet generalisable storytelling practices beyond actors' particular motivation (zooming out). At this advanced praxiographic stage, the coherence of interpretive similarities in the three specific test formats were mapped out according to their key narrative devices (metaphors, roles, plots). There are limitations to this approach in terms of the generalisability of the empirical illustration, since the material is limited in scope and catered to the research interest we have. Therefore, the aim is not to identify causal links, but rather to develop a sensitising framework for the study and exploration of narrative legitimation politics, which might be stimulating for the study of other political controversies.

\section{Exploring narrative legitimation politics around the Snowden controversy}

The controversy around the Snowden disclosures in the US and Germany is explored on three levels as different kinds of tests. Justificatory practices in truth tests are examined through the prism of the Obama and Merkel administrations' direct response to the Snowden revelations and their attempts to both show their loyalty to the surveillance state and justify ongoing surveillance measures. The interplay between justification and critique in reality tests will be analysed through the prism of US congressional hearings, the Bundestag, the judiciary, and elite newspaper opinion pages. Lastly, dominant justificatory practices in existential tests will be shown through various alternative sources.

\section{Surveillance as a truth test: Betrayal, guaranteeing freedom, and uncertainty as a quest}

Consistent with Boltanski, we identified three justificatory truth test practices concerned with confirming and guaranteeing the established order. The first practice is the interpretation of the disclosures in terms of disorder, danger, and threat and the demonisation of Snowden as a traitor. A second justificatory practice is the construction of the polity as a body politic to 'guarantee freedom'. Third, truth tests are applied when the disclosures are narrated as a Manichean struggle between the forces of good and evil.

\section{The making of a traitor}

After initial revelations, executive forces reacted to assuage potential worries and prevent them from becoming elements of wider critique against the state's security institutions. A first step towards the

\footnotetext{
${ }^{82}$ Ibid.

${ }^{83}$ Steffek, 'The legitimation of international governance'.

${ }^{84}$ Grimmel and Hellmann, 'Theory must not go on holiday'.

${ }^{85}$ Stefan Groth, 'Political narratives/narrations of the political', Narrative Culture, 6:1 (2019), pp. 1-18.

${ }^{86}$ Juliet Corbin and Anselm Strauss, Basics of Qualitative Research: Techniques and Procedures for Developing Grounded Theory, Vol. 3 (Thousand Oaks, CA: SAGE Publications, 2008), p. 183.
} 
activation of the register of the truth test was simple denial through claims that the US government was not collecting private information. ${ }^{87}$ However, confirmation is not noiseless. That is, denial was subsequently replaced by a demand for blind faith. Instead of providing additional clarifications, surveillance activities were repetitively presented as necessary actions designed to prevent terrorist attacks in a post-9/11 world. Although it appears as a mere rhetorical move, executives rely on a more complex regime of engagement inherent to modern states to reinforce its own self-image of a provider of security for its citizens in an anarchical international environment.

Within such an order of justification, Snowden became narrated as a diverter, a signifier of disorder and decline, while the surveillance practices themselves were framed as just. Snowden was 'not acting ... with noble intent. ... What Snowden has revealed has caused irreversible and significant damage to our country and to our allies. ${ }^{, 88}$ Interestingly, democratically elected heads of states in both countries replicate the NSA's attempt to control the controversy through the narrative configuration of Snowden as a traitor, when, for example, President Obama advocated a 'thoughtful fact-based debate that would then lead us to a better place, ${ }^{89}$ while later adding, that he 'will not apologize simply because our [intelligence] services may be more effective'90 in areas in which the American public cannot know the 'complete story'. 91

This mode of justification indicates the state sees itself in a permanent state of war while ordinary citizens naively believe it is in peacetime. Accordingly, critique is rejected via the justificatory practice of confirmation as based on flawed assumptions about the reality of the state. While perceptions of peacetime indicate that threats are local and isolated, thereby falling within the rule of law, seeing the state as permanently in war means finding 'itself split between a surface reality, apparent but partly or completely illusory, and an underlying reality, hidden but authentic'. ${ }^{92}$ The aim of stopping terrorist attacks before they occur allows law enforcement to transgress the rule of law and legitimate intelligence work, thereby creating 'fact-based discussions' about the 'totality of circumstances'. ${ }^{93}$ Thus, the impulse to justify covert data gathering after the disclosures forced executive forces to adopt the narrative structure of a spy fiction following the principal function of modern states as security providers. Embracing this structure, 'presupposes viewing all citizens and even all human beings, whether present on the national territory or acting from a distance, as real or potential suspects'. ${ }^{94}$ Consequently, it is not surprising the then German Office of Protection of the Constitution head stated, 'Snowden may have plundered the NSA like no one before him ${ }^{\prime 95}$ when information leaked that German chancellor Merkel was spied on by American intelligence officers.

\section{The state as the 'guarantor of freedom'}

The justificatory practice of the traitor places the truth test on a friend/foe moral binary. Here, truth is not found empirically on the surface level of reality. On the contrary, it is configured as naturally implied within an existing order framed as in constant danger unlike the civil liberties that occasionally undermine its validity. This justificatory practice conceives of liberty as a 'free

\footnotetext{
${ }^{87}$ Luke Johnson, 'Obama defends NSA programs, says Congress knew about surveillance', The Huffington Post (7 June 2013).

${ }^{88}$ John Cassidy, 'Demonizing Edward Snowden: Which side are you on?', The New Yorker (24 June 2013).

${ }^{89}$ Doug Mills, 'Obama's remarks at a news conference', New York Times (9 August 2013).

${ }^{90}$ Barack Obama, 'Speech on NSA phone surveillance', New York Times (18 January 2014).

${ }^{91}$ BuzzFeed Politics, 'President Obama defends NSA spying', BuzzFeed (17 June 2013).

${ }^{92}$ Luc Boltanski, Mysteries and Conspiracies: Detective Stories, Spy Novels and the Making of Modern Societies (Cambridge: Polity Press, 2014), p. 123.

${ }^{93}$ General Michael Hayden, 'W\&L Law Cybersurveillance Symposium Keynote', YouTube (Channel wlulaw) (28 January 2015), available at: $\{$ https://www.youtube.com/watch?v=VUEuWiXMkBA\}.

${ }^{94}$ Boltanski, Mysteries and Conspiracies, p. 128.

${ }^{95}$ Hans-Georg Maaßen, 'Maaßen attackiert NSA-Enthüller Snowden', Deutscher Bundestag (9 June 2016).
} 
necessity'; that is, as the ability of a person to discover that one 'is freer if one understands the necessity of security than if one struggles for more civil liberties'. ${ }^{96}$

Thus, a second important justificatory practice is the construction of the state as the 'guarantor of freedom'. In a political system that imagines itself as a pluralist order, contentions of essentialism usually cause discomfort. Nevertheless, tensions caused by the traitor narrative are resolved by the state reconfiguring itself as a Hobbesian body politic. When demonisation is mobilised via the justificatory practice of the traitor, essentialising what must be protected or enforced as a 'free necessity' becomes a corresponding practice: 'A lot of very thoughtful members of our body politic are saying all right, the President, the Congress and the courts are on board, but that doesn't constitute consent of the governed any more; that's consent of the governors. You told them, but you didn't tell me, and fundamentally I think that's the crisis of oversight. ${ }^{97}$

Evoking the idea of a body politic, citizens are confronted with images of everyday people unable to survive without the political forces of the polis, such as the NSA. Justified on the normative ground of the state's basic effort to monopolise violence for everyone's safety, surveillance appears as a shield: 'intelligence community measures (are) used to keep Americans safe' and 'the state must compensate the loss of control over communication of criminals with new laws and technology tools ${ }^{98}$ to prevent 'at least 50 threats'. 99 This points to a nexus of demonisation and essentialisation since security measures, according to executive forces, have proven efficient. This is, for instance, communicated through quantifications of saved lives as evidence that Snowden was 'reckless' and caused 'huge, grave damage' to the body politic. ${ }^{100}$ Interestingly, rapidly expanding technology gives credence to visions of a menacing invisible threat. The digital sphere is accordingly a lawless yet political world in which seemingly endless threats exist, enabling an expansion of the traitor justificatory practice. This opens new possibilities for executive forces to further ingrain their justificatory practices. When Chancellor Merkel, for example, supported President Obama's contentions, she also confirmed that these measures were necessary because: "The Internet is new, uncharted territory to all of us. And it also enables our enemies. It enables enemies of a free, liberal order, to use it, to abuse it, to bring a threat to all of us, to threaten our way of life. And this is why we value cooperation with the United States on questions of security. ${ }^{\text {101 }}$

\section{The Manichean struggle}

A third embedded justificatory practice is the configuration of the present as a quest for assurance and continued existence. This is mediated through the metaphor of the Internet as new, uncharted territory (Neuland) of the body politic; that is, a lawless world that necessitates the wise guidance of those already entrusted with power to oppose those "who threaten our way of life'. ${ }^{102}$ This is achieved through the format of the truth test by a specific mix of fact and fiction that embraces brooding images of an emerging future while referencing to a nostalgically transfigured past in which national identity is preserved. An apocalyptic image of the future is transmitted here that presents the state as a necessary hegemon who exercises interpretive power over the present to legitimise its own repressive behaviour. The more menacing the images of a

\footnotetext{
${ }^{96}$ Dumitrina Galantolu, 'The Big Brother fear: Four perspectives on surveillance', American Intelligence Journal, 33:1 (2016), pp. 59-64 (p. 61).

${ }^{97}$ Hayden, 'W\&L Law Cybersurveillance Symposium Keynote'.

${ }^{98}$ Former German Interior Minister Hans-Peter Friedrich quoted in Schulze, 'Patterns of surveillance legitimization', p. 204.

${ }^{99}$ The White House, 'Joint Press Conference by President Barack Obama and German Chancellor Angela Merkel' (19 June 2013).

${ }^{100}$ See Aaron Blake, 'Clapper: Leaks are "literally gut-wrenching”, leaker being sought', The Washington Post (9 June 2013); Johnson Mitchell et al., 'Intelligence chief declassifies PRISM details, slams "reckless disclosures”, NBC News (8 June 2013). ${ }^{101}$ Ibid.

${ }^{102}$ Ibid.
} 
potential outcome if 'loss of control over communication' is not compensated with 'new laws and technology tools', the more likely one is to accept extraordinary state measures. This fictional account is supported by a cultural tradition that suggests the inevitable presence of countervailing moral forces. As General Hayden explains: ${ }^{103}$ 'We Americans in the National Security Agency ... we have historically been Manichean about the rest of the world. Are you, or are you not protected by the Fourth Amendment to the US Constitution? Are you? Oh my God, we can't touch you. Are you not? Game on! ... That's a legitimate principle, and it's real fuzzy. And so we'll see how that evolves going forward.'

Being Manichean means thinking in the dualistic terms of religious wars between godless and god-fearing peoples. Crucially, it reveals the important role of narratives in the unfolding of the surveillance controversy in general and the justificatory practices of executive forces, in particular. Promoted during the Cold War by leading US figures in key institutions engaged with geostrategic issues, ${ }^{104}$ it became a semantic framework for truth tests to legitimise authority in the surveillance controversy. However, in this case Manicheism is not restricted to visions of America as a sacred entity and a 'target of hate because of its freedoms' (George W. Bush). It is instead retold as 'evolving and fuzzy' and in need of operational renewal whereby inside and outside, the public and the private are irreversibly blurred.

Surveillance programs are thus presented as beyond the reach of the enforcement of the Fourth Amendment, which prohibits unreasonable searches and seizures of power. As David Gray has argued, the 'culprit is not the Fourth Amendment itself. ... The problem lies instead in the Supreme Court's Fourth Amendment jurisprudence, which fails to set reasonable constitutional constraints on the deployment and use of these means and methods. ${ }^{105}$ However, reasonableness became a matter of a wider Manichean worldview in which privacy is the line we continuously negotiate between ourselves as unique creatures of God and ourselves as social animals. In the first category we have a right to keep things to ourselves. And in the second category we have a responsibility to reveal things about ourselves to the community for the greater good. ${ }^{106}$ From the perspective of the intelligence sector's epistemic communities, Obama's promise of not monitoring private internet activity is a necessary move to respond to liberal critique corresponding to the rule of law. However, following the Manichean worldview, as the NSA does, 'the greater good' must be protected, therefore legitimising intrusive data collection practices and transforming a legal question into a political one, as is usual for justificatory practices in truth tests.

\section{Justificatory practices in truth tests}

In legitimation disputes such as the NSA controversy, a standard justificatory practice is the attempt to describe the controversy, metaphorically speaking, as a 'trial by fire'. In this narrative configuration, the executive forces are unexpectedly put under pressure to prove their power against insidious actors who aim to destroy the established political order. The characterisation of Snowden as a traitor and enemy of the state legitimises its glorious own role as a brave defender. In this case, a plot pattern of a quest is developed whereby the established order and their defenders must embark on a quest into the unknown future. The success of this mission can only be guaranteed by the courage of its main protagonists (here: the NSA and other executive forces). In this narrative construction, the heroes are naturally those who guarantee security through effective policy and therefore must be willing to put out the fire by all means necessary. This is charged through a form of normativity whereby the security of all must be guaranteed,

\footnotetext{
${ }^{103}$ Hayden, 'W\&L Law Cybersurveillance Symposium Keynote'.

${ }^{104}$ Lynn Boyd Hinds and Otto Windt Jr, The Cold War As Rhetoric: The Beginnings, 1945-1950 (London and New York: Praeger, 1991).

${ }^{105}$ David Gray, The Fourth Amendment in an Age of Surveillance (Cambridge: Cambridge University Press, 2017), p. 249.

${ }^{106}$ Hayden, 'W\&L Law Cybersurveillance Symposium Keynote'.
} 
and those standing in the way are considered dangerous dissidents to be dealt with within a law-and-order framework. Those who do not declare their loyalty to the political order are regarded as a suspicious figures and potential threats.

\section{Surveillance as a reality test: Arbitration, historical analogies, and disillusionment}

Following Boltanski's reality test, this format focuses on scrutinising claims within institutional means. Truth claims are tested through agreed routines in investigations, reports, and reforms requiring qualified judgement by actors such as parliamentarians, judges, and mainstream journalists. ${ }^{107}$ The critical claims here are thus reformist and not radical. ${ }^{108}$ The aim is hence not to overthrow the established order. Instead, correcting what has gone wrong occurs by 'confirming the existing order or criticizing it for not living up to its own ideals'. ${ }^{109}$ The three central narrative justificatory practices identified here are arbitration of the law, historical analogies, and expressions of disillusionment.

\section{Arbiter of the law}

While executive forces in truth tests affirm a specific truth interpretation maintaining the status quo, reality tests examine the validity of claims through routinised, institutional mechanisms. One justificatory practice observed in various moral claims around the Snowden revelations is the arbiter of law, whereby errors are remedied through democratic application of the law and, if necessary, reform.

Immediately after the revelations, an international debate ensued about reigning in surveillance by overhauling regulatory frameworks, albeit with scepticism towards Snowden. US Representative Jim Sensenbrenner accused the executive of 'justifying vacuuming call records from millions of innocent Americans', thereby necessitating 'more rigorous oversight'. ${ }^{10}$ In Germany, similar narrative variants of this justificatory practice could be observed in the opposition's response in the NSA committee, ${ }^{111}$ created to examine Snowden's revelations and the involvement of the German federal government by committee member Konstantin von Notz: 'the German government must immediately and forcefully insist that all actions of this sort cease and be monitored'. ${ }^{112}$ In the committee, the opposition Left and Green Party members contended the Federal Intelligence Agency had 'on various occasions acted unlawfully' ${ }^{113}$ whose activity could not be sufficiently monitored by the executive who had failed to 'create paper or electronic files', thereby hindering democratic exchange. ${ }^{114}$ Accordingly, von Notz embodied the role of defender of the law by emphasising the necessity to guarantee citizens' rights: ${ }^{115}$ 'Democracies must have clear and precise instruments to follow the people you have suspicions against. You can't just collect data, go through it, and construct things against people.'116

\footnotetext{
${ }^{107}$ Boltanski, On Critique, p. 106.

${ }^{108}$ Ibid., p. 108.

${ }^{109}$ Rob Stones, 'Strengths and limitations of Luc Boltanski's On Critique', in Susen and Turner (eds), The Spirit of Luc Boltanski, p. 222.

${ }^{110}$ Ibid. The reform focused on replacing the controversial Patriot Act, specifically Section 215, which the executive interpreted as allowing mass surveillance of Americans' private information. The new law, the Freedom Act, banned the mass collection of private calls and internet activity, becoming the most important surveillance reform since 1978

${ }^{111}$ An NSA spying scandal committee was set up in the Bundestag, whose goal was to write a final report to address the disclosures and draft reforms. The report created government-oppositional rancor. See 'Beschlussempfehlung und Bericht des 1. Untersuchungsausschusses gemäß Artikel 44 des Grundgesetzes', Deutscher Bundestag (23 June 2017).

${ }^{112}$ Jefferson Chase, 'NSA spying scandal committee presents controversial final report', Deutsche Welle (28 June 2017).

${ }^{113}$ Kai Biermann, 'Opposition wirft Regierung Lüge vor', Zeit Online (19 June 2017).

${ }^{114}$ Ibid.

${ }^{115}$ NSA inquiry committee a "big success"', DW News (28 June 2017).

${ }^{116}$ Ibid.
} 
In the US, this justificatory practice proved important in reforming the 2001 Patriot Act. US Senator Mark Udall interpreted the original intent of the law as follows: 'Congress clearly intended this authority to be used to collect the communications of foreigners - not Americans - yet the Director of National Intelligence recently confirmed that the NSA, CIA and FBI conduct warrantless searches of communications of Americans .... ${ }^{117}$ Regarding CIA torture practice reform and the executive's withholding of surveillance information, Senator Dianne Feinstein stressed: 'We're not going to stop. I intend to move to have the findings, conclusions and the executive summary of the report sent to the president for declassification and release to the American people. ${ }^{, 18}$ Feinstein emphasised 'how this is resolved will show whether the Intelligence Committee can be effective in investigating our nation's intelligence activities, or whether our work can be thwarted by those we oversee'. ${ }^{119}$ Typical of the reality test, the fluctuating ambivalence between critique and justification characterises understandings. Feinstein thus added: 'I believe it is critical that the committee and the Senate reaffirm our oversight role', ${ }^{120}$ nevertheless holding Snowden's actions amounted to 'an act of treason'. ${ }^{121}$

\section{Historical analogies}

A further identified justificatory practice is contextualisation through historical precedent to evaluate a dispute's merits. In the case of the reality test, this narrative construction draws parallels between historical examples that (de)legitimise positions, ultimately testing what is deemed acceptable. Here, three significant figures played a role: American civil rights leader, Martin Luther King (MLK), the German protestant reformist, Martin Luther, and the American Vietnam whistleblower, Daniel Ellsberg.

During a debate on the revelations, Senator Rand Paul, suggested former CIA head 'Clapper and Snowden should share a jail cell, where they could talk about liberty and security', ${ }^{122}$ thereby equating the dissenter and the executive's violations. Accordingly, Paul was drawing on injustices committed by officials and crimes deemed necessary by dissidents such as Snowden who does not 'deserve a death penalty or life in prison; I think that's inappropriate, and I think that's why he fled, because that's what he faced. ${ }^{123}$ A common narrative element for this justificatory practice is the evoking of formerly tarnished civil dissidents key to eventual reforms and institutional change: 'On deciding when you decide to become a civil disobedient - we've had famous ones in our career, but some of them only had to serve, like Thoreau only had to serve one day in jail, Martin Luther King served only 30 days ....'124 Senator Paul moreover evoked MLK to criticise the executive for implementing spying practices that reminded him of 'J. Edgar Hoover's illegal spying on Martin Luther King. ${ }^{125}$ These examples show that actions formerly considered illegitimate can later be narrativised in more sympathetic terms.

In Germany, among other historical analogies, parallels were drawn to the sixteenth-century protestant Theologian Martin Luther. In this context national cultural peculiarities become evident. In an interview article entitled 'Is Snowden the Modern Luther?' ${ }^{126}$ with Antje Vollmer, former Bundestag Vice President, comparisons were made between their moral bravery against

\footnotetext{
${ }^{117}$ Kate Tummarello, 'Key Senate Dems push for stronger NSA reform', The Hill (29 July 2014).

${ }^{118}$ Dianne Feinstein, 'Dianne Feinstein statement on CIA torture report “cover-up"', The Guardian (11 March 2014).

${ }^{119}$ Ibid.

${ }^{120}$ Ibid.

${ }^{121}$ Jeremy Herb and Justin Sink, 'Sen. Feinstein calls Snowden's NSA leaks an "act of treason”', The Hill (10 June 2013 ).

${ }^{122}$ Timothy Edgar, 'Obama's mixed legacy on cybersecurity, surveillance, and surveillance reform', in David Gray and Stephen E. Henderson (eds), The Cambridge Handbook of Surveillance Law (Cambridge, UK: Cambridge University Press, 2017), p. 77.

${ }^{123}$ Brian Knowlton, 'Senators differ sharply on penalty for Snowden', New York Times (5 January 2014).

${ }^{124}$ Tal Kopan, 'Paul: Snowden “civil disobedient”, Politico (18 June 2013).

${ }^{125}$ Jamelle Bouie, 'Is Rand Paul's MLK analogy offensive?', Slate (24 March 2014).

${ }^{126}$ Maon Prieber, 'Ist Snowden der moderne Luther?', evangelisch.de (16 August 2013).
} 
an unjust system and their rebellion to improve it. Typical of this narrative practice, notions of Snowden as a traitor are dismissed through comparison: 'This is complete nonsense! Luther sensed an opportunity for a comprehensive spiritual liberation and wanted to reform the church internally. And Snowden also simply wants the USA to become a really free country again. He fights for "Western values" more than his critics. ${ }^{127}$

Parallels were furthermore drawn between Snowden and Daniel Ellsberg in the media and among politicians and whistleblowers. ${ }^{128}$ Citing Ellsberg's revelations, The Guardian ('A Whistleblower, not a Spy') and The New York Times ('Edward Snowden, Whistle-blower') called for justice for Snowden resembling Ellsberg's story, who had vindicated himself. ${ }^{129}$ Typical of this justificatory practice, it is submitted that any 'charges against him should be ones to which it is possible to mount a public interest defense, of the sort that was mounted by Daniel Ellsberg'. ${ }^{130}$ Along these lines, The New York Times ${ }^{131}$ admitted Snowden is similar to figures such as Daniel Ellsberg ... now broadly regarded as a person of admirable moral convictions'. Journalist Douglas Rushkoff, similarly made the connection. 'You'd think we would be even more outraged by what he uncovered than we were by the surveillance of Ellsberg ... Snowden has not uncovered a human conspiracy here but the workings of the machine itself. ${ }^{132}$ Mainstream journalism was therefore a key aspect of judging what counts as acceptable dissent. Importantly, the analogies show the centrality of narrative in terms of assigning roles to specific disputing personalities and weaving them into a coherent, moral story.

\section{Disillusionment}

A final identified justificatory practice of the reality test is the expression of disillusionment towards violators of the order's rules whose strong emotionality resembles the existential test. This justificatory practice becomes relevant, for instance, after the executive fails to provide sufficient oversight, thereby confirming the system is not working as intended. An aim of this narrative operation is to emphasise motifs such as shame and embarrassment, thereby mounting pressure to permit observation.

Disillusionment in the US was expressed regarding the lack of cooperation on handing over torture and surveillance documents. During a debate on CIA spying on congressional members after the Snowden revelations, Senator Feinstein defiantly expressed: 'I continue to believe CIA's actions continued a violation of the constitutional separation of powers ... I'm disappointed that no one at the CIA will be held accountable. ${ }^{, 133}$ Disillusionment was likewise conveyed by Senator Wyden towards former CIA head James Clapper after his infamous testimony admitting the CIA 'could inadvertently collect' Americans' private data, 'but not wittingly'. ${ }^{134}$ Here, too, the justificatory practice can be observed in Senator Wyden's discouraged reaction: 'Now public hearings are needed to address the recent disclosures, and the American people have the right to expect straight answers from the intelligence leadership .... ${ }^{135}$

\footnotetext{
${ }^{127}$ Ibid.

${ }^{128}$ Ellsberg leaked information pertaining to the Johnson and Nixon administrations who used false pretenses to launch the Vietnam War.

${ }^{129}$ See 'Edward Snowden: A whistleblower, not a spy', The Guardian (2 July 2013) and 'Edward Snowden, whistle-blower', The New York Times (1 January 2014).

${ }^{130}$ Ibid.

${ }^{131}$ Ibid.

${ }^{132}$ Douglas Rushkoff, 'Edward Snowden is a hero', CNN (11 June 2013).

${ }^{133}$ Dianne Feinstein, 'Feinstein Statement on CIA Accountability Review Board, IG Reports', Press Release (14 January 2015).

${ }^{134}$ Aaron Blake, 'Sen. Wyden: Clapper didn't give “straight answer” on NSA programs', The Washington Post (11 June 2013).

${ }^{135}$ Scott Shane and Jonathan Weisman, 'Earlier denials put intelligence chief in awkward position', New York Times (12 June 2013).
} 
In the Bundestag, similar justificatory practices were noted, especially during the debate on allowing Snowden's testimony in investigatory committee. ${ }^{136}$ Ultimately, a visa for Snowden was denied by then Interior Minister de Maizière, resulting in wrangling between the opposition and the CDU/SPD government. In response, Green committee leader von Notz expressed disillusionment as 'a damning indictment' of an executive engaging in 'unprecedented un-parliamentary behavior'. ${ }^{137}$ After the German Federal Constitutional Court denied Snowden's testimony, the opposition Green and Left committee members exhibited the typical practice of disillusionment: 'We very much regret that there was not even the opportunity to present this to the court at an oral hearing. ${ }^{, 38}$ After the German Federal Court of Justice definitively denied testimony, the leading Left committee member resorted to disillusionment to create political pressure: 'This is politically frustrating, because large parts of the international surveillance scandal are now unresolved: Germany could've played a pioneering role. A wasted opportunity.'139

This justificatory practice became evident in the US judiciary. A Florida circuit court judge was disheartened by the Obama administration, stating 'What right does law enforcement have to hide behind the rules and to listen in and take people's information like the NSA? ... Inhibiting law enforcement's rights are second to protecting mine!' ${ }^{140}$ This disillusioned motif was also expressed in other court rulings, for example in a federal circuit court ruling against an NSA metadata program under Section 215 of the Patriot Act ${ }^{141}$ found that Congress never ratified such behaviour: 'We would expect such a momentous decision to be preceded by substantial debate, and expressed in unmistakable language ... Congress cannot reasonably be said to have ratified such a program of which many members of Congress - and all members of the public - were not aware. ${ }^{142}$

\section{Justificatory practices in reality tests}

The interplay between justification and critique in reality tests revolves around a 'critical moment' as an opportunity to fix the problem. Descriptions of the situation centre on minor scratches in the system, necessary adjustments, and solutions to the problem. In these justificatory practices, the reflexive capabilities of participating actors are highlighted as discussing how to minimise the gap between 'is' and 'ought' through democratic means. Furthermore, the ambivalence of Snowden as a whistleblower is contested normatively. Indeed, the critical congressional summary on Snowden shows that it 'had become axiomatic to heed Snowden, while denying that one was doing so'. ${ }^{143}$ The moral characterisation therefore ranges from negative attributes (troublemaker) to neutral and even positive ones (reformer / enlightener). Whereas in truth tests the underlying normativity of the narrative is clearer (loyalty vs defection), the competing justificatory claims mirror the open end of the reality test. The actors therefore struggle in their moral claims between reflexivity and obedience. Collective confusion is translated into the narrative emplotment of a comedy by which a solution to the crisis is achieved by creating a better situation through

\footnotetext{
${ }^{136}$ Jefferson Chase, 'NSA spying scandal committee presents controversial final report', Deutsche Welle (28 June 2017).

${ }^{137}$ Ibid.

${ }^{138}$ Matthias Meisner, 'Linke und Grüne: Wir sind enttäuscht', Der Tagesspiegel (12 December 2014).

${ }^{139}$ Ibid.

${ }^{140}$ Ellen Nakashima, 'Secrecy around police surveillance equipment proves a case's undoing', The Washington Post (22 February 2015).

${ }^{141}$ For a general resource on various codenames for global metadata collection programs, see $\{$ https://www.electrospaces. net/p/nicknames-and-codewords.html\}.

${ }^{142}$ Randy Barnett, ' $2 \mathrm{~d}$ circuit holds NSA bulk data seizures unauthorized by USA Patriot Act', The Washington Post (7 May 2015).

${ }^{143}$ Robert Jervis, quoted in in Rhodri Jeffreys-Jones, We Know All About You: The Story of Surveillance in Britain and America (Oxford: Oxford University Press, 2017), p. 219.
} 
democratic means. As is usual for comedies following White, ${ }^{144}$ the world is understood optimistically: Crises ameliorate the world through democratic reconciliation.

\section{Surveillance as an existential test: Ordinary hero, canonisation, dystopic prophecy}

In contrast to reality tests, in which the interplay between critique and justification results in an agreement between disputing actors to accept established rules, the existential test is characterised by its radicality. ${ }^{145}$ Critical actors do not see themselves as reformers, but rather embody refusal and resistance. The aim is to overcome institutional structures whose fundamental hypocrisy needs to be exposed to unmask 'the reality of relations of force, exploitation, and domination'. ${ }^{146}$ Three justificatory practices (the ordinary man becoming a hero, the whistleblower as a saviour, the dystopic prophecy) are identified, which are illustrated through popular culture media such as protest, art, film, and autobiography.

\section{The ordinary man becoming a hero}

While executive forces in truth tests characterise Snowden as a traitor to delegitimise his motivations, this practice of critique is driven by the opposite aim. Snowden is narrated as an ordinary man who transforms into a hero responding to an immoral development, which forces him to act in a selfless, albeit tragic, way. His motifs are true and honest, not driven by fame seeking. In his autobiography Permanent Record, for instance, Snowden laments it was easier to 'come forward with evidence of government wrongdoing ... than ... to give an account of my life. ${ }^{147}$ Snowden traces both his moral foundation and fascination for computers to a lifechanging gift he received from his patriotic military family in the late 1980s: a Nintendo Entertainment System with the game Super Mario Bros. ${ }^{148}$ This moment was told as the beginning of his 'real education, 149 upon which he would build his moral framework: that is, the simple hero on a world-saving quest against the evil empire. The reader understands how Snowden developed a sense of idealism based on the seemingly endless possibilities offered by the Internet, spending most of his time on the computer on various forums developing a sense of community. ${ }^{150}$ It becomes clear that Snowden found a way to use his passion and grift to eventually become a high-level NSA operative, jet-setting throughout the world by his mid-twenties with access to the agency's most secret files.

In these moments of an ordinary man's naïve discovery, the plot pattern switches from a comedy-like success story to a tragedy. The story is told such that Snowden sensed a certain amount of dread and neuroticism surrounding the NSA's activities based on the changes he was witnessing politically and online. Activating a moral framework through which he perceived himself as a small - but necessary - cog in the wheel, Snowden frantically combed through documents proving what he feared and eventually hit pay dirt: XKeyscore, PRISM, ECHELON, etc. This moment is crucial for critique as the ordinary man is forced to decide between conformism and heroism. The justification for blowing the whistle follows a tragic plot: Snowden justifies his rebellious act as losing faith in the institutions to resolve the matter on their own, thereby seeing himself as the only actor capable of guaranteeing the transmission of truth to the public. ${ }^{151}$

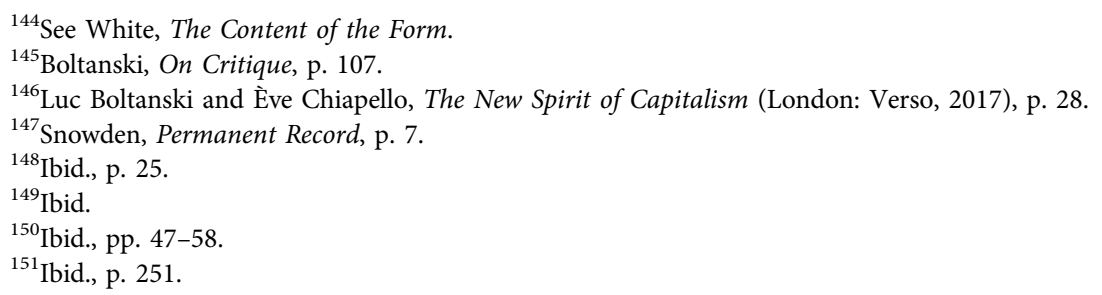


This is similarly narrated in the documentary Citizenfour, directed by Laura Poitras, that covers Snowden's escape in the summer of 2013 as NSA documents entrusted to journalists leak to the public. ${ }^{152}$ The director allows viewers to witness Snowden differently through the prism of his sincere motivations in becoming a whistleblower. This on-the-ground view forces one to confront the immense human cost of exposing the innerworkings of the increasingly intrusive international surveillance nexus.

As Snowden nervously reveals the NSA's shocking widespread intrusive practices on screen, the film transmits another important message: The humanisation of the mysterious then 29-year-old computer wunderkind. Snowden is filmed through the perspective of the everyday when combing his hair, brushing his teeth, relaxing on his hotel bed, nervously reflecting, and chatting with his girlfriend online. Snowden is portrayed in situations with which we can all relate: he is just like us. The emotional rollercoaster, the various points of empathy, and the magnitude of what Snowden reveals all within the claustrophobic atmosphere of an omniscient surveillance state, confined hotel rooms, and restrictive border laws make for a compelling critical work. Through an intimate interview format in a small hotel room, Snowden insists this is not a quest for fame or glory: 'I'm not the story here', becoming an emblematic slogan for his critical supporters.

\section{The whistleblower as a saviour}

A similar heroic retelling as a justificatory practice can be observed in Oliver Stone's epic Snowden, which goes even further by portraying the whistleblower as a saviour-like being embodying the people's struggle against dark forces. This stoically tireless, even mythical, character embarks on a fight for justice to protect the basic ideals of the US Constitution. Typical of this justificatory practice, the characterisation switches from the sympathetic hero to a nearly sacrosanct figure contradicting the traitor justificatory practice of the truth test. This canonisation makes him untouchable. The unequal power balance is made clearest in visual imagery in a scene in which Joseph Gordon-Levitt, playing Snowden, enters a NSA conference room, becoming visible to others as a large screen is switched on. Snowden makes a video call to a man who, as a powerbroker between the secret security and political worlds, doubts Snowden's previously unbroken loyalty. At first, the mighty figure can only be seen in the background of the office. However, he begins to take on menacing godlike traits from a distance, while the camera focuses on Snowden from behind as a small, powerless protagonist. In the course of the scene, the unequal power distribution becomes extreme as the mighty figure moves closer to the webcam, thus appearing even bigger and eerier as Snowden shrinks. Snowden is confronted by an uncontrollable and overpowering Big Brother. However, conscious of his strength, he does not flinch. The film strives to convey that Snowden could not rely on anyone as an ally, ultimately forcing him to wage a moral battle within himself.

The canonisation of Snowden is also a major element in public protests, particularly in Germany, characterised by unusual enthusiasm to his revelations and defiance. ${ }^{153}$ Indeed, an unusual amount of iconography and art projects were created in the aftermath Snowden's disclosures. Most ubiquitous was perhaps the work of a Berlin advertising agency, Zitrusblau, ${ }^{154}$ which adapted Obama's iconic Shepard Fairey image of HOPE and replaced it with an image of Snowden with the word 'ASYL' (asylum in German). Activist groups, such as Compact, supported efforts to give Snowden asylum in Germany and spread the image in various social media outlets. Suddenly, t-shirts, stickers, graffiti, and posters featuring this image spread

\footnotetext{
${ }^{152}$ Laura Poitras (dir.), Citizenfour (Berlin: Praxis Films, 2014).

${ }^{153}$ Harriet Torry, 'Edward Snowden emerges as a cult hero in Germany', The Wall Street Journal (24 September 2014). See also Stefan Steiger, Wolf Schünemann, and Katharina Dimmroth, 'Outrage without consequences? Post-Snowden discourses and governmental practice in Germany', Media and Communication, 5:1 (2017), pp. 7-16 for the discrepancy between the German public and government's responses to the disclosures.

${ }^{154}$ Ibid.
} 
throughout German urban centres and social media, becoming a visual centrepiece of protests against a growing, menacing surveillance state. Snowden's willingness to accept legal consequences gives credence to treating his decisions as self-sacrificing, as emphasised by Snowden in a conversation in Citizenfour: 'I'm more willing to risk imprisonment than I am willing to risk the containment of my intellectual freedom and those around me.'155

\section{The revelation as a dystopic prophecy}

While the other two justificatory practices already operate with tragic elements of storytelling, the moment of revelation can be also justified and told as a clear sign for dystopian imaginaries of future worlds. Critical actors therefore often work with a broad spectrum of references in popular culture, sci-fi novels, and films for example, making sense of the confusing reality and criticising executive forces' justificatory practices as trivialising. Not surprisingly, George Orwell's dystopic 1984 and Philip K. Dick's sci-fi novel Minority Report became popular cultural references after Snowden's disclosures.

In Citizenfour, Poitras demonstrates Snowden's fear of being monitored in his everyday practices to transmit dystopic visions to the audience. In one scene, Snowden disconnects his telephone's power plug since, so he explains, 'anyone can wiretap us'. In one bewildering scene, Snowden throws a 'magic sheet' over himself to hide how he types passwords on his laptops. At the end of the documentary, viewers see how, due to fear of being wiretapped, Greenwald and Snowden only communicate via written notes. Although such scenes can be also perceived as staged, they provide viewers with a feeling of distrust and paranoia about an infringing surveillance state around them, inciting memories of how all hotel room guests panic when a fire alarm suddenly rings. As ridiculous it seems to throw a sheet over one's head before using a computer, the viewer also assumes Snowden, a former NSA contractor, knows he what he is doing. The storytelling in Citizenfour produces an uncomfortable feeling for viewers that every action in an everyday life is under state surveillance. Such scenes evoke dystopic imageries and similarly produce a sense of sarcastic humor about an overreaching state.

In Permanent Record, however, we see another deadly serious element of this dystopic justificatory practice: the historical catastrophe. In one passage of his autobiography, Snowden gives an example of the monstrous consequences of some changes in supposedly harmless technical procedures in the everyday. ${ }^{156} \mathrm{He}$ explains how the Nazi German census of 1939 used statistics, assisted by computer technology, to count the German Reich's population, to control it and purge it - mainly of Jews and Roma - before exerting its murderous efforts on populations beyond its borders'. ${ }^{157}$ To achieve this, as Snowden writes, the Reich partnered with Dehomag, a German subsidiary of the American IBM corporation, which owned the patent of the punch card tabulator, a sort of analog computer that counted holes punched into cards. Each citizen was represented by a card, and certain holes on the cards represented certain markers of identity. Shortly thereafter, this census information was used to identify and deport Europe's Jewish population to death camps. The storytelling effect of such an example is clear, the reader is forced to think about similar consequences of the current surveillance state, which might evolve from contemporary everyday security practices, such as routinised smartphone use.

\section{Justificatory practices in existential tests}

The practices of criticism in existential tests exhibit metaphorical descriptions of the dispute as a brand new, and potentially revolutionary, revelation. Existential justificatory practices primarily

\footnotetext{
${ }^{155}$ Ibid.

${ }^{156}$ Snowden, Permanent Record, pp. 183-5.

${ }^{157}$ Ibid., p. 183.
} 
mobilise moral and emotional registers. They strive to accentuate insufficiently articulated experiences of exclusion, make further accusations, and thus create awareness of the contingency of the status quo. In this case, Snowden is characterised as a heroic citizen ${ }^{158}$ who struggles in a patriotic fight against corrupt and overpowering political structures. The underlying normativity in this narrative pattern is therefore the opposite to truth tests: the need for resistance and civil obedience plays against the shadowy state apparatus that declares any form of critique as paranoid. Leading figures of resistance, such as whistleblowers, can even be portrayed as religious, mythical figures, willing to self-sacrifice in a morally rotten world. This test often follows the plot of tragedy as the justified fight against the system is narrated as a hopelessness and desperate endeavour, potentially ending (in this case) in dystopian terms of dictatorship and total control.

\section{Conclusion}

The exploration above outlines a practice-oriented conceptual framework for the empirical study of narrative legitimation politics. Importantly, it shows controversies such as the Snowden revelations are characterised by a multitude of interpretations that strive for legitimacy via justificatory practices expressed through test formats in (non-)institutional contexts. However, the spatiotemporal fluidity of narrative dynamics also points to spillover between the test formats, resulting in junctures of potential change. For example, the justificatory practices of historical analogies in the reality test and the dystopic prophecy in the existential test both employ the past and future to (de)legitimise actions, oftentimes drawing upon the same historical figure or event. Civil society initiatives such as 'Necessary and Proportionate' moreover demonstrate how the line between formats straddles. ${ }^{159}$ Similarly, justificatory practices that call on the rule of law as seen in truth and reality tests also create opportunities for agreement to cement a certain interpretation of an unfolding dispute. Oppositional justificatory practices that are very similar in substance, such as the Manichean struggle and the Whistleblower as a saviour, result in friction between the test formats that can more deeply polarise the controversy and further galvanise their target audiences. As such, these narrative dynamics demonstrate that legitimacy is always 'in the making' through justificatory practices that artfully tap into normative registers that resonate with audiences' everyday experiences. Indeed, one element of a justificatory practice, such as a metaphor or a characterisation, can wander from test format to another, providing the potential to shift dynamics and effect political change.

This conceptual suggestion therefore seeks to sensitise researchers of complex political controversies to the fluid, and oftentimes contradictory, dynamics of legitimacy production by capturing its contingency and interpreting its meaning. Although it has been argued that legitimacy claims are created in the everyday, there is still a lack of conceptual and empirical work in IR in general, and critical security studies in particular, which connects legitimacy research with the variety of justificatory practices and their storytelling embeddedness in specific cultural contexts. As we argued in this article, the methodological orientation of praxiography, as part of the intellectual project of international practice theory, provides new avenues for IR scholar to study similar political controversies. As the production of normativity in international practices remains one of the key challenges, ${ }^{160}$ our conceptual suggestion of narrative legitimation politics provides a

\footnotetext{
${ }^{158}$ For an analysis of how Snowden and other whistleblowers portray their own actions to various audiences see, for example, Daphne Inbar, 'For Whom the Whistle Blows? How National Security Whistleblowers Narrate their Own Stories to International Publics', draft paper presented at the EISA Conference in Sofia (2019).

${ }^{159}$ See \{necessaryandproportionate.org\}. Civil society actors such as this group often utilise both legal and activist narrative elements mending practices from both reality and existential test formats. Thank you to the reviewers for bringing this to our attention.

${ }^{160}$ See Bueger and Gadinger, International Practice Theory, pp. 110-16; Frank Gadinger, 'The normativity of international practices', in Alena Drieschova, Christian Bueger, and Ted Hopf (eds), Conceptualising International Practices (Cambridge: Cambridge University Press, forthcoming 2021).
} 
promising way to overcome the artificial separation between norms and practices in most IR research. ${ }^{161}$ The focus on justificatory practices enables a practice-oriented view on the normative contestation of governance concepts such as transparency, ${ }^{162}$ which underlines that rules and meaning are never fixed but need to be understood in and through practical enactment. The uncertainty of such moments of dispute, expressed in the pragmatist notion of 'test', allows researchers to reconstruct how critical actors employ normative orders in their 'legitimation work'. ${ }^{163}$ Such a pragmatic view on normative ordering between competing moral claims is characterised by its enmeshed nature of acting and knowing. Justificatory practices (like other practices) derive from background knowledge, practical understandings, and situated learning that is shared and established within a community.

The proposed methodological orientation is hence useful for the analysis of a constantly fluctuating international environment in which formerly agreed-upon values and rules are being disputed in an extraordinary manner. Snowden's revelations and the ensuing legitimacy crisis is just one example of this. International protest movements such as Black Lives Matter, Fridays for Future, and Pulse of Europe demonstrate the persistent contestation and moral ambiguity that currently characterise contemporary politics. Unprecedented global crises such as refugee movements, climate change, the COVID-19 pandemic, and economic instability signal this trend will continue. Therefore, we hope our contribution will inspire other scholars to empirically study how justificatory practices shape narrative legitimation politics in a fundamentally uncertain and seemingly unstable world. A potential pathway forward could examine how the identified justificatory practices, such as the narrative ambivalence of Snowden as a traitor or saviour, apply to other controversial figures and issues (for example, Greta Thunberg, Chelsea Manning, Jamal Khashoggi). A comparative view on different policy fields across cultural contexts could provide insight into how moral narratives shift over time, ultimately creating further polarisation feeding into transformations such as the global rise of right-wing populism. ${ }^{164}$ The combination of pragmatic sociology and narrative analysis provides one promising methodological pathway forward for IR scholars and beyond to explore these research challenges.

Acknowledgements. Earlier versions of this article were presented at the ISA conference in Baltimore (2017) and the EISA conference in Sofia (2019). We thank the participants for their valuable suggestions. We are especially grateful to Andreas Baur, aline shakti franzke, Katja Freistein, Daphne Inbar, Sebastian Jarzebski, Karl-Rudolf Korte, Max Lesch, Philipp Michaelis, Holger Niemann, Sabrina Pischer, and Jens Steffek for close critical readings and essential comments. Research for this article has benefited from support of the Hans Böckler Foundation, the NRW School of Governance (University of Duisburg-Essen), and the Käte Hamburger Kolleg/Centre for Global Cooperation Research (University of Duisburg-Essen).

Christopher Smith Ochoa is a doctoral candidate at the NRW School of Governance of the University of Duisburg-Essen, Germany. His research examines questions of inequality through the lens of narrative in political phenomena such as urban riots, surveillance, and economic inequality. He is currently a doctoral scholarship holder of the Hans Böckler Foundation for his dissertation on narratives in the contemporary German economic inequality discourse. He has published in Critical Policy Studies; Leviathan; and Narrative Culture.

Frank Gadinger is currently guest professor at the Technical University of Darmstadt and Senior Researcher at the Centre for Global Cooperation Research, University of Duisburg-Essen, Germany. His main research interests lie in the practice turn in International Relations, political narratives, visual global politics, global governing, and the rise of populism. He recently published the second edition of the book International Practice Theory (with Christian Bueger) by Palgrave MacMillan. His

\footnotetext{
${ }^{161}$ See also Simon Frankel Pratt, 'From norms to normative configurations: A pragmatist and relational approach to theorizing normativity in IR', International Theory, 12:1 (2020), pp. 59-82.

${ }^{162}$ Similarly Daniel McCarthy and Matthew Fluck, 'The concept of transparency in International Relations: Towards a critical approach', European Journal of International Relations, 23:2 (2016), pp. 416-40.

${ }^{163}$ Geuss, Philosophy and Real Politics p. 35.

${ }^{164}$ Boltanski (Mysteries and Conspiracies), for instance, argues that the rise of globalised capitalism accompanied a counternarrative of sovereign nation states in control of the world, thereby provoking constant doubt about this claim. Thank you to the reviewers for bringing this to our attention.
} 
publications have appeared in journals such as International Political Sociology; International Studies Quarterly; Leviathan; Narrative Culture; and Review of International Studies.

Taylan Yildiz is currently guest professor at the NRW School of Governance, University of Duisburg-Essen, Germany. Besides his interest in political narratives, his research focuses on conceptualiaing a practice-oriented approach to political transformations in Turkey. Furthermore, he is currently working on a book on heuristics. He has published in Politische Vierteljahresschrift; Leviathan; Narrative Culture; and Zeitschrift für Politikwissenschaft.

Cite this article: Smith Ochoa, C., Gadinger, F., Yildiz, T. 2021. Surveillance under dispute: Conceptualising narrative legitimation politics. European Journal of International Security 6, 210-232. https://doi.org/10.1017/eis.2020.23 